\title{
Integration of Histology Lectures and Practical Teaching in China
}

\author{
Xiaoye $\mathrm{Lu}^{1 \#}$, Xin Cheng ${ }^{1 \#}, \mathrm{Ke} \mathrm{Li}^{1}$, Kenneth $\mathrm{Ka} \mathrm{Ho} \mathrm{Lee}^{2} \&$ Xuesong Yang ${ }^{1}$ \\ ${ }^{1}$ Division of Histology and Embryology, Key Laboratory for Regenerative Medicine of the Ministry of Education, \\ Medical College, Jinan University, Guangzhou, China \\ ${ }^{2}$ Key Laboratory for Regenerative Medicine of the Ministry of Education, School of Biomedical Sciences, Chinese \\ University of Hong Kong, Shatin, Hong Kong \\ \#Contributed to this work equally \\ Correspondence: Xuesong Yang, Division of Histology and Embryology, Key Laboratory for Regenerative Medicine \\ of the Ministry of Education, Medical College, Jinan University, Guangzhou 510632, China. Tel: 86-20-85228316
}

Received: September 7, 2016

Accepted: September 28, 2016

Online Published: October 13, 2016

doi:10.5430/ijhe.v5n4p157

URL: http://dx.doi.org/10.5430/ijhe.v5n4p157

\begin{abstract}
Objectives: Human histology is a discipline concerning the study of microscopic structures of human tissues and organs - with the aid of light or electron microscopes. Traditional teaching of histology is composed of two separated components, theory and practice. The main disadvantage with traditional histology teaching is the detachment of theory and practice, so that students could not completely and systematically comprehend histology. Methods: To supplement the deficiencies of traditional histology teaching, we implemented the integrated curriculum of the theory and practice on histology at Jinan University School of Medicine. The aim of the integrated curriculum is to enhance students' learning efficiency. During the course, teaching patterns as "lecture-practice-lecture-practice" and "practice-lecture-practice" were alternatively employed according to the content. We attempted to guide students to verify the theory using practice, and to conduct practice simultaneously using theoretical knowledge. Results: We assessed the tests scores of students participating and non-participating in the new integrated curriculum at the end of semester. We found that the average test score, pass rate and excellent rate were significantly higher in participating than non-participating students. The follow-up questionnaire survey revealed that the better exam results was derived from maximizing the use of time in class, encouragement of students' learning initiatives, mastering of key points and arrangement of theory and practical teaching more appropriately in the integrated course. Conclusions: Our results demonstrated that integrated teaching indeed improved the students' histology learning outcomes.
\end{abstract}

Keywords: Histology, Graduate medical education, Integration, Theory and practice

\section{Introduction}

Human histology, also called microanatomy, is a discipline concerning the study of microscopic structures of human tissues and organs - with the aid of light or electron microscopes. Histology is one of the compulsory courses for medical students, since it allows the students to acquire basic knowledge of normal tissues and organs before their proceeding courses in pathology and pathophysiology. As an anatomical sub-discipline, the histology curriculum for medical students is usually delivered in the second semester of $1^{\text {st }}$ school year in China. Until several years ago, all of the histology and embryology courses were taught in the traditional manner at Jinan University School of Medicine. It consisted of didactic lectures given in the classrooms and then followed by laboratory practical where students are expected to master the microscopic features and functions of various tissues and organs by themselves. The time proportioned to theory and practical is 1:1. Hence, one major problem that students encounter is that they may have forgotten the theories taught during lectures before they attend their histology practical classes several days later. In addition, the traditional teaching format can also make medical students lose interest in learning histology because they have to first memorize the morphology of many kinds of cell and tissue types from their lectures or textbooks before their histology practice.

In contemporary Chinese society, it was often complained that the new doctors were lack of practical experiences but overloaded with theoretical concepts. However, this does not imply that medical students spend less time on practicing various disciplines in medical school (Huang et al., 2014; Sun et al., 2012). Specifically, these phenomena might not only exist in China. The young clinical doctors, who undertake intensive work in hospitals, have to continue studies to satisfy the numerous demands in clinical setting. Some reasons account for these problems, such 
as the medical technology advances, emergence of new diseases, and extension of related medical knowledge (Klement et al., 2011). However, the effectiveness of the traditional medical teaching system has also been questioned, whether it is adapted well to the current needs of modern medicine, and the current requirements in interdisciplinary pre-clinical and clinical practice (Custers \& Cate, 2002). Traditionally, most of medical educational approaches include didactic lectures given in the classrooms and followed by laboratory or clinical practical days after, where students are expected to verify and master the theoretical knowledge. There is clearly an unacceptable time gap between theory and practical teaching amongst different medical disciplines, as well as within a single discipline like histology. The main disadvantage with traditional histology teaching is the detachment of theory and practices, so that students could not completely and systematically comprehend histology. Unnecessary redundant teaching hours must be used to link up the contents. Therefore, we should re-think about the traditional teaching approach.

In recent years, some new teaching approaches such as problem-based learning (PBL) has been the dominant format for teaching medicine in more and more medical schools around the world (Fincham \& Shuler, 2001; Trappler, 2006). Integration of the medical curriculum presents learning not only in vertical direction between basic and clinical science but also in horizontal non-discipline specific courses (Hassan, 2013; Ward, 2010). There is no doubt that integrated medical courses have initiated a radical movement from traditional curricular format in medical education (Muller et al., 2008) . As a backbone of medical science, anatomy is generally integrated into the clinical relevant normal human biology. The anatomical curricular changes in the integrated course include placing laboratories and lectures more consistently, decreasing didactic lectures, eliminating unnecessary duplication of content, and increasing students engagement of self-regulated learning time (Hoffmann \& Swailes, 2014; Jonassen et al., 2016; Klement et al., 2011) . Integrated medical courses have been gradually accepted by many medical schools, because they appear to improve student learning attitude and satisfaction in comparison with traditional forms of learning. Nevertheless, due to the complexity of integrating a curriculum, only $19 \%$ of medical courses in the United States, 24\% in Canada and less than $3 \%$ in China have adopted integrated teaching methods in undergraduate medical education (Huang et al., 2014; Spencer et al., 2008; Sun et al., 2012) .

In particular, unlike gross anatomy, medical students may lose the macroscopic perspective during observation of the much smaller structures by microscope. Another dilemma is that they may not readily be aware of the importance of histology. However, the ability to understand the change of cells and tissues in pathology situation, provides the future doctors with the knowledge to interpret symptoms and make diagnosis. Therefore, in order to put the available teaching-learning time to better use, and get a better outcome of histology teaching, we integrated the theories and practice into a new curriculum and implemented it at Jinan University School of Medicine. Our teaching staff have tried to ensure that the medical students are not only well-versed in theoretical acknowledge but also know how to apply it during practice. In this context, we produced a novel histology curriculum where the theoretical teaching was implemented simultaneously with laboratory demonstration. It was designed to remove the temporal-spatial barrier that existed in the traditional mode of learning, and to promote students' ability to study efficiently and generate interest in histology to obtain a better learning outcome. We investigated the effectiveness of our new intergraded histology teaching by comparing it with the traditional form of teaching.

\section{Methods}

\subsection{Study Design}

The pilot histology curriculum was conducted in Clinical Medicine students at Jinan University School of Medicine. The traditional teaching was used as the control. In the traditional teaching pattern, histology theory and practice were separately taught to medical students. The content of the integrated course was exactly same as the content of traditional histology teaching but was delivered differently. The same histology textbook was employed for both groups of students. Moreover, the two groups of students were tested with the same examination papers, and the papers were graded by same teachers at the end of semester. Simultaneously, questionnaires were designed using Sojump to obtain feedbacks from students participating in the new integrated histology course.

\subsection{Participants}

The pilot integrated histology curriculum was conducted in medical students enrolled from overseas in 2014 at Jinan University School of Medicine. The histology curriculum is offered to sophomore oversea Chinese students of Clinical Medicine during the $3^{\text {rd }}$ semester. The total time allocated to histology teaching is 108 hours, in which 54 hours are assigned for theoretical lectures and 54 hours for laboratory practice. In our traditional didactic teaching, the theoretical session occupies a full 120-minute lecture in the classroom per week, and laboratory practice is a 120-minute long of viewing histological slides. A total of 24 Clinical Medicine students were recruited on a 
voluntary basis to participate in the integrated pilot program.

Table 1. Plan used for teaching histology of Epithelium Tissues

\section{Integrated histology teaching (total of 3 sessions, together 120 minutes long)}

\section{Class session 1}

\section{Initiation of teaching}

Teacher's action

Students participation

Materials \& equipment Time

(minutes)

Teacher questions students on the Students answer.

different types of tissues.

\begin{tabular}{|c|c|c|c|}
\hline \multicolumn{4}{|l|}{ Body of teaching } \\
\hline Teacher's action & Students participation & Materials \& equipment & $\begin{array}{l}\text { Time } \\
\text { (minutes) }\end{array}$ \\
\hline $\begin{array}{l}\text { Teacher explains the characteristics } \\
\text { of epithelial tissues \& how they are } \\
\text { distributed. }\end{array}$ & Students listen. & $\begin{array}{l}\cdot \text { Courseware } \\
\cdot \text { Computer multimedia } \\
\text { teaching system }\end{array}$ & 10 \\
\hline $\begin{array}{l}\text { Teacher guides viewing of the } \\
\text { histological slides, asking students } \\
\text { to locate the epithelia \& appreciate } \\
\text { the arrangement of the cells \& } \\
\text { extracellular matrix. }\end{array}$ & $\begin{array}{l}\text { Students observe slides of the gall } \\
\text { bladder. }\end{array}$ & $\begin{array}{l}\cdot \text { Light microscopes } \\
\cdot \text { Virtual microscopy }\end{array}$ & 10 \\
\hline $\begin{array}{l}\text { Teacher explains the different types } \\
\text { of simple epithelia, morphology \& } \\
\text { arrangement. }\end{array}$ & Students listen. & $\begin{array}{l}\cdot \text { Courseware } \\
\cdot \text { Computer multimedia } \\
\text { teaching system }\end{array}$ & 15 \\
\hline
\end{tabular}

Short 10 minutes break

\section{Class session 2}

\section{Body}

Teacher action

Students participation

Materials \& equipment Time

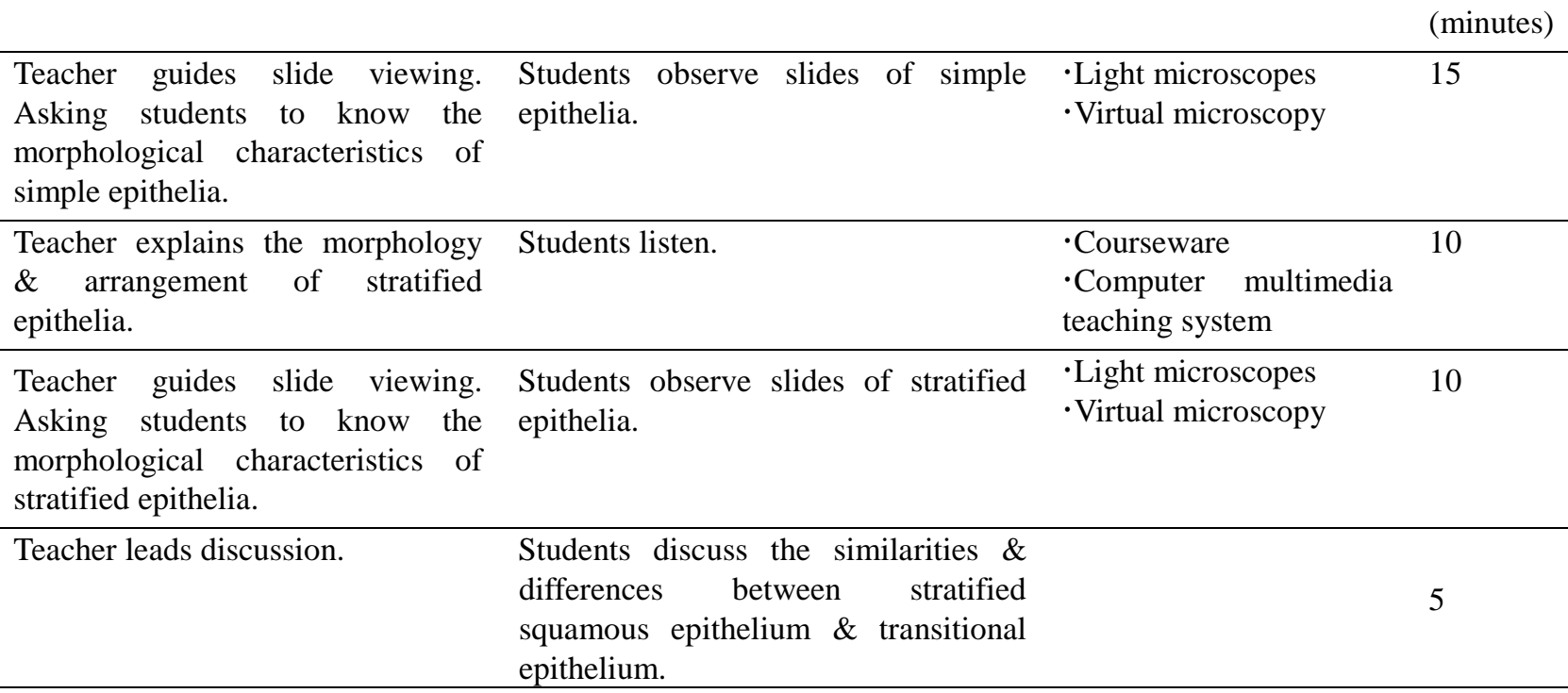

Short 10 minutes break 


\section{Class session 3}

\section{Body}

Teacher action

Students participation

Materials \& equipment Time

Teacher summarizes different Students respond. types, arrangement \& functions of epithelial tissue.

Teacher explains glandular Students listen.

epithelia \& glands.

Teacher guides slide viewing. Telling students to distinguish the acinus $\&$ ducts, the serous gland \& mucous gland.

$\begin{array}{ll}\text { Teacher conducts on-class practical } & \text { Students are required to recognize } \\ \text { quiz. } & \text { various epithelia via the computer } \\ & \text { multimedia teaching system within a } \\ & \text { limited time. Each group will select } \\ & \text { one student to take part in this quiz. } \\ & \text { The students exchange to revise the } \\ & \text { answers. }\end{array}$

Home works are handed out. Students are asked to draw what they see \& complete the homework using a digital panoramic system \& Blackboard course website.

$\begin{array}{llll}\begin{array}{l}\text { Students observe slides of the } \\ \text { submandibular gland. }\end{array} & \begin{array}{l}\cdot \text { Light microscopes } \\ \cdot \text { Virtual microscopy }\end{array} & 10\end{array}$

(minutes)

- Courseware 5

- Computer multimedia

teaching system

- Courseware 10

- Computer multimedia

teaching system

- Virtual microscopy

$\cdot$ Computers
-Computer multimedia
teaching systems
$\cdot$ Pen \& Paper

- Light microscopes

- Virtual microscopy

- Blackboard course website
10

5

Institutional review board (IRB) approval was not requested for the present study, because no sensitive personal information was involved. All data were anonymized. All participants were provided with oral and written information about the nature of the study, and informed that they could withdraw from the study at any time. Confidentiality was assured by keeping the materials de-identified in the transcripts, and the data in this study were only accessible to the authors.

\subsection{Curricular Implementation}

The integrated histology course was taught in the morphology laboratory twice a week and 120 minutes long every session. The theory and practice were allocated in a $2: 1$ proportion. In the course, teaching patterns "lecture-practice-lecture-practice" and "practice-lecture-practice", were alternatively employed according to the content. Here, we focused on the Epithelial Tissues session as an example to illustrate how we implemented the integrated teaching regime in each histology session (Table 1). "Lecture-practice-lecture-practice" was employed for teaching epithelial tissues. The teacher first explained the definition and characteristics of epithelial tissues, and then guided the students to recognize epithelial tissues and cells under the microscope by themselves immediately after the theory teaching. The students would realize that the cells are closely packed and there are less extracellular matrix in epithelial tissue, since the teacher just taught the subject. The teacher would teach the next session after students have completely mastered the histology of epithelial tissues. This approach is similar to that of the traditional teaching format. However, the difference is mainly to adjust the time interval between theory lectures and student laboratory practice. Another pattern was adopted as "practice-lecture-practice-lecture", for example this was employed in the study of muscular tissues. Firstly, teacher would guide students to observe three types of muscles in order to let them acquire perceptual knowledge of these tissues before lectures. Then, the lecture would follow where students are taught the characteristics of various muscle tissues based on their practical observations. Subsequently, the students were asked to observe the histological slides of muscles again.

\subsection{Data-collection Methods}

The test scores of the two groups of students were collected from their final examination papers by two members of the research team independently. Respondents completed all surveys online. Their responses populated an 
anonymous, confidential database in Sojump that captured de-identified aggregate information. All surveys collected were reviewed and generated the results.

\subsection{Data Analysis}

Statistical and graphical analysis was performed by GraphPad Prism 5 software package. Two tailed $t$-test was used to compare the test scores of integrated course participants and non-participants. The data generated were presented as mean \pm standard deviation (SD). The experimental group was considered to be significantly different from the control when $p<0.05$, and highly significantly different when $p<0.01$.

\section{Results}

\subsection{Pilot Integrated Histology Theory and Practice Teaching Delivered to $2^{\text {nd }}$ Year Medical Students}

The pilot study for integrating histology theory and practice teaching was designed for medical students enrolled from overseas in 2014 at Jinan University School of Medicine. Total 69 medical students were enrolled and 24 of these students voluntarily participated in the pilot study, while the remaining 45 non-participants acted as the control. The class venue was in the morphology laboratories based at Jinan University Medical School. The laboratories housed histology slides, light microscopes, computers with digital panorama imaging system and internet access for every student. The content of the integrated course is exactly same as the content of traditional histology teaching.

\subsection{Pilot Integrated Histology Course Improved the Test Scores of Medical Students}

To assess the effectiveness of the integrated histology teaching, we analyzed the test scores of the participants $(n=24$, experimental) with non-participants $(n=45$, control) at the end of the semester. The results showed that the average test scores for participants of the integrated teaching and non-participants were $75 \pm 3.46$ and $63.96 \pm 2.53$, respectively. This indicates that the new integrated histology courses significantly enhanced the learning outcome of participating students (Figure 1, $p=0.012$ ).

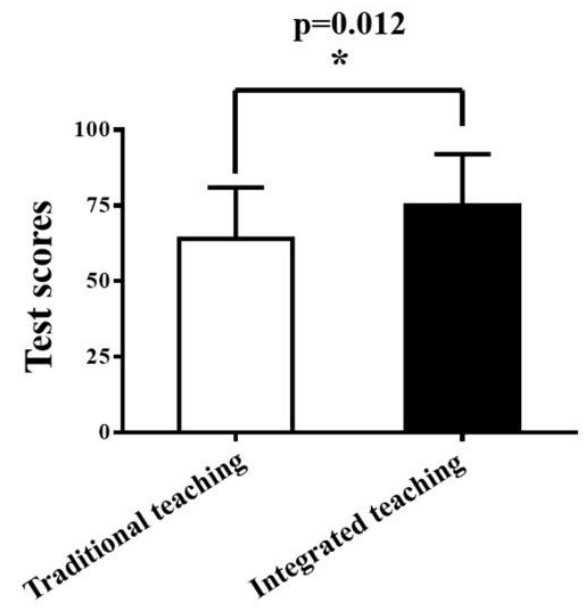

Figure 1. Comparison of test scores from students taught by traditional and integrated teaching methods

Participants ( $\mathrm{n}=24$, experimental) and non-participant students $(\mathrm{n}=45$, control) of the integrated histology course took the same histological examination at the end of semester. The $100 \%$ points system was used in the exam. The bar chart shows the comparison of students' average scores from traditional and integrated teaching groups. ${ }^{*} p<0.05$ indicates significantly difference between both groups.

The effectiveness of the integrated histology teaching was further evaluated by analyzing the pass rate and rate of excellence in the histology examination (Figure 2). At Jinan University School of Medicine, we used a 100 percentage point system in the histology examination and a pass grade was awarded if the score was over $60 \%$. The score was considered as excellent if it was over $80 \%$. The results revealed that the pass rate of integrated course-participants (experimental) was $88 \%$ which was much higher than students taught by traditional didactic teaching $(74 \%$, control). Furthermore, the excellence score rate for participants was $45 \%$, which was significantly higher than non-participants, $12 \%$ (Figure 2). Both sets of results suggest that integrating histology theory and practical teaching enhances the learning outcome of histology in medical students. 


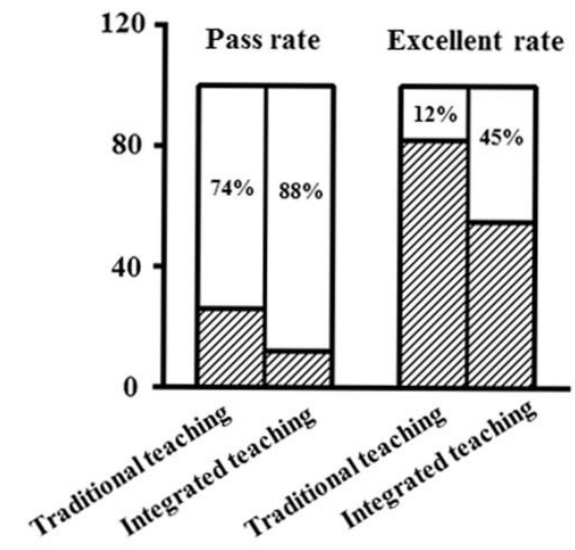

Figure 2. Comparisons of the pass and excellent examination rates of students taught by traditional and new integrated methods.

The test scores of the same population of medical students were analyzed. It was based on how many students pass the examination and how many students obtained an excellent score - taught by either traditional or new integrated methods. The bar chart shows the comparisons of the pass and excellent rates of both groups of students.

\subsection{The Questionnaire Survey Revealed that the Medical Students Benefited from the Format of Integrated Course}

A questionnaire was designed to obtain feedback from all students that had participated in the pilot integrated histology course. The aim was to collect useful information from the students' perspective, besides assessment of students' test scores. In the questionnaire, one of the questions asked was related to whether or not the integrated course was able to maximize the students' learning time. It was established that $61.5 \%$ of the integrated course-participants agreed while $23.1 \%$ participants disagree and $15.4 \%$ did not know (Figure $3 \mathrm{~A}$ ). We also asked whether the pilot course inspired student's interest in histology, 75.4\% of participants agreed while $6.2 \%$ disagreed (Figure 3B). The vast majority of participants $(87.1 \%)$ think that the format of the integrated course enhanced their understanding of the key concepts in histology as oppose to traditional didactic teaching, and only $4.4 \%$ of participants disagreed (Figure 3C). The students were asked if the time allotment between theory and practice is appropriate in the integrated course, $72.3 \%$ participants answered yes and only $7.3 \%$ said no (Figure 3D). In summary, we can conclude that the majority of participating students have a positive view of the integrated histology course.
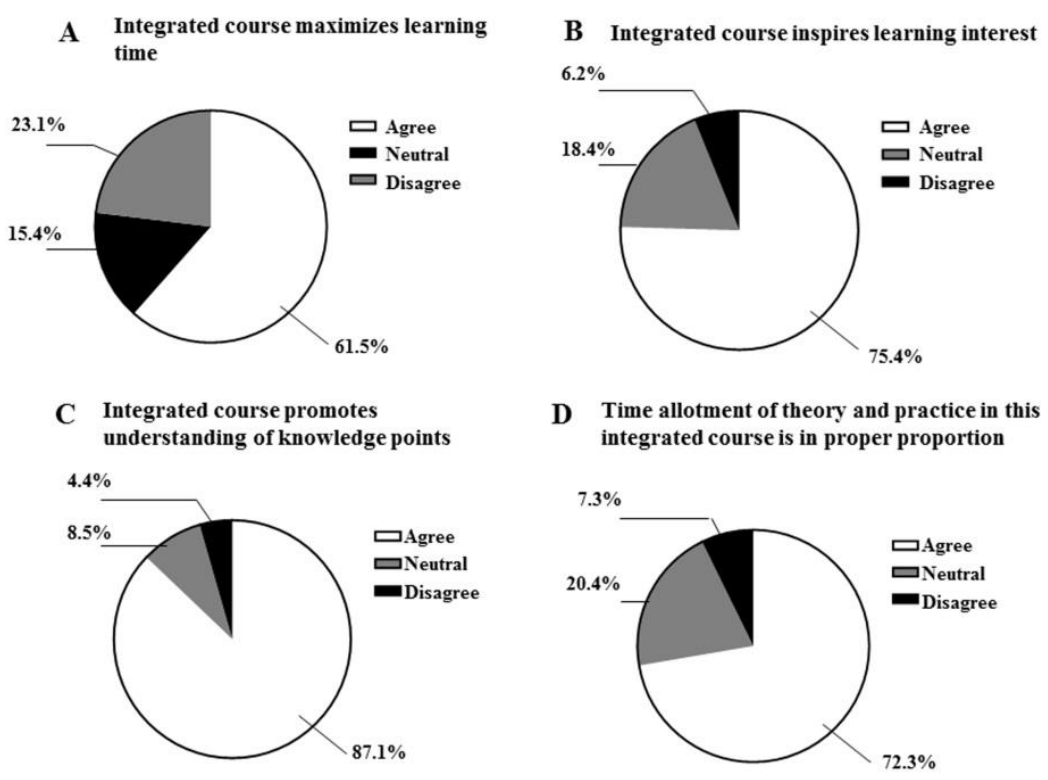

Figure 3. Questionnaire survey on student feedback of the integrated histology course

All participants of the integrated course $(n=24)$ were asked to answer all of the questions in the questionnaire. A-D: Bar charts showing the percentage of the participants' answers. 


\section{Discussion}

The traditional method of teaching histology at Jinan University is consisted of a didactic lecture followed by a practical session. The advantage of this format includes its systematisms and integrity of the teaching agenda (Dahle et al., 2002), so that medical students are able to systemically study basic knowledge of medicine. The critical shortcoming of this format is the gap between theoretical study and practical application in laboratory. During the lecture, the teacher explains the microstructures of tissues and cells based on pictures in the textbooks, which would not immediately impact on the students in the classroom. This in turn could make it difficult for students to understand the theory of the histological structures being taught. Teachers may have to repeat the theoretical content when students attend the histology practice - since there is a time lag between the lecture and following practice (Tsinopoulos et al., 2014). Hence, we have found the teaching outcome was not as satisfactory as we wanted due to the extra time being used during the practical session to repeat theories already taught during lectures. In contrast, in our pilot integrated histology course, we determined that student learning initiative and efficiency were dramatically improved and this was reflected in their end of semester examination results. The average test score of the integrated course students was significantly better than students taught using the traditional teaching method. Likewise, the pass rate and the excellence rate for the integrated course were also significantly higher than the traditional form of teaching.

The effectiveness of the integrated histology course was highlighted by the examination result which was much higher than expectation. We decided conduct a questionnaire survey to understand the reason for the dramatic improvement in participating students. The questionnaire showed the participating students were able to maximize the use of their study time in the integrated course without extra hours being added. The questionnaire also revealed that the format of the integrated course enhanced interactions between teachers and students, which inspired the students to take greater interest in histology. The students suggest that the close spatiotemporal interaction between teachers and students allow them to better understand the key concepts in histology. The students also mentioned the arrangement of class schedule was more reasonable than in our traditional teaching. Taken together, all these positive factors additively improved the learning outcome in the integrated histology course.

In the feedback from participating teachers, the majority supported the integrated course. They observed students were more enthusiastic and improve their study outcomes. However, most of them admitted that they had to spend more time preparing for the integrated course than in the traditional teaching format. It was a challenge for them to balance their time between teaching and scientific research. Another important requirement of the integrated course is the classroom setting and number of teachers. Since the course is set in the morphology laboratories, the capacity for hosting students is limited. If the integrated course is extended to all medical students, we would require more laboratories equipped with digital panorama imaging system and multi-media teaching system to satisfy the teaching needs (Kumar et al., 2006) . Likewise, more histology tutors are needed to guide students in the integrated courses. From the point of view of both students and teachers, the integrated course is inelastic since they have been used to the traditional teaching format.

\section{Conclusions and Limitations}

The tutors should consider the following advantages with the integrated course: 1) it resolves the disconnect problem between histology theory and practice - keeping the integrity of histology teaching; 2) it reduces the repetition of teaching histology theory during practical lesson - enhancing teaching efficiency (Pipas et al., 2004) ; 3) it increases interaction between students and teachers - promoting student interest in histology; and 4) it helps teachers identify students with problems while observing histological slides and immediately solve it. In this context, we propose that integrated histology teaching is a better mode for learning histology and meets the increasing needs to modernize medical education. The results generated from our investigation will indicate whether the integrated approach could be applied to other disciplines such as the teaching of gross anatomy.

Undoubtedly, several limitations in this study should be discussed. The first limitation is that all of the participants of the trial were volunteers. It is possible that the volunteers may have different characteristics and abilities from non-participants, example as self-guided learning, motivation and independence. In order to generate a more robust comparison, participants should be randomly selected to prevent potential biases. Moreover, this study only involved a relatively small sample of medical students and the results were extrapolated from and pertained primarily to histology teaching. Therefore, the integrated course should be extended to other medical disciplines and conducted on a larger pool of medical students to avoid result biases. Achieving more integration among topics is our ultimate goal to be accomplished step by step in the future years. 


\section{Acknowledgments}

We would like to thank Jian-long Chen for assistance in data analysis. This study was supported by funding from $17^{\text {th }}$ Research Projects of Pedagogical Reform at Jinan University (JG2015071) and Chinese outstanding doctors' training program of Ministry of Education.

\section{Conflict of interest}

The authors declare that there are no conflicts of interest.

\section{References}

Custers, E. J., \& Cate, O. T. (2002). Medical students' attitudes towards and perception of the basic sciences: a comparison between students in the old and the new curriculum at the University Medical Center Utrecht, The Netherlands. Med Educ. 36(12), 1142-1150. http://dx.doi.org/10.1046/j.1365-2923.2002.01371.x

Dahle, L. O., Brynhildsen, J., Behrbohm Fallsberg, M., Rundquist, I., \& Hammar, M. (2002). Pros and cons of vertical integration between clinical medicine and basic science within a problem-based undergraduate medical curriculum: examples and experiences from Linkoping, Sweden. Med Teach. 24(3), 280-285. http://dx.doi.org/10.1080/01421590220134097

Fincham, A. G., \& Shuler, C. F. (2001). The changing face of dental education: the impact of PBL. J Dent Educ. 65(5), 406-421.

Hassan, S. (2013). Concepts of vertical and horizontal integration as an approach to integrated curriculum. Education in Medicine Journal. 5(4), e1-e5. http://dx.doi.org/10.5959/eimj.v5i4.163

Hoffmann, D., \& Swailes, N. (2014). GRISTO: an integrated learning experience in Gross Anatomy and Histology for Dental Students, learning outcomes and student perspectives on curriculum change (532.4). FASEB J. $28(1$ Supplement), 532.534 .

Huang, L., Cheng, L., Cai, Q., Kosik, R. O., Huang, Y., Zhao, X., Xu, G. T., Su, T. P., Chiu, A. W., \& Fan, A. P. (2014). Curriculum reform at Chinese medical schools: what have we learned? Med Teach. 36(12), 1043-1050. http://dx.doi.org/10.3109/0142159x.2014.918253

Jonassen, J. A., Gilroy, A. M., Joseph, M., Florman, H. M., Wendie, A., \& Fischer, M. A. (2016). A First-Year Medical School Course Integrating Development, Structure, and Function. Med Sci Educ. 26(1), 31-33. http://dx.doi.org/10.1007/s40670-015-0197-4

Klement, B. J., Paulsen, D. F., \& Wineski, L. E. (2011). Anatomy as the backbone of an integrated first year medical curriculum: design and implementation. Anat Sci Educ. 4(3), 157-169. http://dx.doi.org/10.1002/ase.217

Kumar, R. K., Freeman, B., Velan, G. M., \& De Permentier, P. J. (2006). Integrating histology and histopathology teaching in practical classes using virtual slides. Anat Rec B New Anat. 289(4), 128-133. http://dx.doi.org/10.1002/ar.b.20105

Muller, J. H., Jain, S., Loeser, H., \& Irby, D. M. (2008). Lessons learned about integrating a medical school curriculum: perceptions of students, faculty and curriculum leaders. Med Educ. 42(8), 778-785. http://dx.doi.org/10.1111/j.1365-2923.2008.03110.x

Pipas, C. F., Peltier, D. A., Fall, L. H., Olson, A. L., Mahoney, J. F., Skochelak, S. E., \& Gjerde, C. L. (2004). Collaborating to integrate curriculum in primary care medical education: successes and challenges from three US medical schools. Fam Med. 36 Suppl, S126-132.

Spencer, A. L., Brosenitsch, T., Levine, A. S., \& Kanter, S. L. (2008). Back to the basic sciences: an innovative approach to teaching senior medical students how best to integrate basic science and clinical medicine. Acad Med. 83(7), 662-669. http://dx.doi.org/10.1097/ACM.0b013e318178356b

Sun, P., Huang, J., Bo, Y., \& Hu, W. (2012). Progress and expectation of integrated curriculum in medical education of China. China Higher Medical Education, (5), 62-63.

Trappler, B. (2006). Integrated problem-based learning in the neuroscience curriculum--the SUNY Downstate experience. BMC Med Educ, (6), 47. http://dx.doi.org/10.1186/1472-6920-6-47

Tsinopoulos, I. T., Symeonidis, C., Tsaousis, K. T., Mataftsi, A., Chalvatzis, N., Tzamalis, A., Lamprogiannis, L. P., \& Dimitrakos, S. A. (2014). Contribution of integrated teaching in the improvement of an undergraduate ophthalmology curriculum. Adv Med Educ Pract. 5, 433-437.

Ward, K. P. (2010). Horizontal integration of the basic sciences in the chiropractic curriculum. J Chiropr Educ. 24(2), 194-197. http://dx.doi.org/10.7899/1042-5055-24.2.194 